\title{
Influence of some industrial wastes as a heavy aggregate on durability of concrete upon utilization in the special constructions
}

\author{
Gharieb M ${ }^{1,}$, El-Sayed H A ${ }^{1}$, Abo-El-Enein S A ${ }^{2}$, Sakr K ${ }^{3}$, Ali A H ${ }^{1}$, El-Sokkary T M ${ }^{1}$ \\ 1 Housing and Building National Research Center, Dokki, Cairo, Egypt. \\ 2 Faculty of Science, Ain shams University, Cairo, Egypt. \\ 3 Atomic Energy Authority, Hot Laboratories Center, Cairo, Egypt. \\ Corresponding Author: medo 20109129@yahoo.com
}

Received: 05-11-2017

Revised: 18-02-2018

Accepted: 20-02-2018

\begin{abstract}
The aim of this study is to investigate the effect of some industrial wastes as a heavy aggregate on durability of the concrete after exposure to different effects. The coarse aggregates used to perform the concrete were dolomite (control) and lead slag, while fine aggregate were sand and lead slag aggregate. The physical and mechanical properties of use draw aggregates were determined also the physical and mechanical properties of different types of concrete were studied. The linear attenuation coefficients $(\mu)$ and half value layer $(\mathrm{HVL})$ of gamma rays measurements have been carried out using $\gamma$-rays sources of $\mathrm{Cs}^{173}$ and $\mathrm{Co}^{60}$. Effect of sea water on the mechanical properties of high performance concrete; in addition, corrosion behavior of reinforcing steel embedded in concrete incorporating different aggregates upon exposure to sea water were studied. It was found that, the compressive strength for all concrete mixes made with dolomite and lead slag coarse aggregates satisfy the requirements of compressive strength for high performance concrete (grade-M60) after 28 days of curing in tap water. The results indicate that, the compressive strength values and gamma radiation shielding properties of concrete mix containing lead slag aggregate enhances upon replacing sand by fine portion of lead slag aggregate. The concrete mixes made with lead slag coarse aggregate proved their high endurance and could sustain sea water exposure, achieving compressive strength values exceeding grade M-60 concrete even after 6 months exposure. Lead slag concrete- in spite of its efficient durabilityrequires the incorporation of a corrosion inhibitor to counteract the hostile effect of the high sulfate concrete in the aggregate.
\end{abstract}

Key words: High performance concrete, heavy weight concrete, linear attenuation coefficients $(\mu)$, corrosion behavior of reinforcing steel.

\section{Introduction}

Concrete is one of the most common and important materials used for radiation shielding in nuclear facilities, due to its high compressive strength and high durability (Kharita et al., 2008). Concrete shielding properties depending upon its composition. Different types of special concretes have been developed by changing the aggregate used in concrete, depending on the available natural and artificial local materials. Aggregates are the largest constituent (about 70$80 \mathrm{wt} . \%$ of the total weight) of normal concrete. Concretes with specific gravities higher than $2600 \mathrm{~kg} / \mathrm{m}^{3}$ are called heavy weight concrete and aggregates with specific gravities higher than $3000 \mathrm{~kg} / \mathrm{m}^{3}$ are called heavy weight aggregates according to (TS EN 206-1, 2002). Heavy weight concretes have been widely used as radiation shield materials in nuclear facility. The aggregate of concrete containing heavy elements plays an important role in improving concrete shielding properties and attenuation of photons and neutrons (El-Sayed, 2003; Akkurt et al., 2012). The density of heavy concrete based on the specific gravity of the aggregates and the properties of the other components of concrete. The aggregates and other components are based upon the exact application of the high density concrete. Different experimental measures such as effect of radiation, marine environment and corrosion of reinforcing steel were examined to evaluate the 
durability of high performance concrete and its suitability for utilization in the constructions of nuclear facilities (Ouda, 2014).

In the design of a protective shielding, one of the key factors is preventing the penetration of the rays. The property of the shield material of the most significance in preventing this penetration is its density. Gamma rays originate within the reactor core and attenuation of gamma rays is dependent upon the density of the shielding materials. (Al-Humaiqani et al., 2013), found that the compressive strength of heavy HPCs plays an important role in enhancing the attenuation of gamma rays. The high performance concretes (HPCs) density considerably affects the attenuation of gamma rays. With the increase in the density, the attenuation coefficient increases linearly. (Atzeni et al., 1997) Studied the possibility of using granulated slags resulting from the smelting of lead and zinc in partial, or total replacement of sand in mortars and concretes. The major components of these vitreous slags are $\mathrm{Ca}, \mathrm{Si}, \mathrm{Fe}$ and $\mathrm{Al}$ compounds with lead concentration of a few percent. The slag mortars and concretes studied yielded satisfactory mechanical strengths. (Alwaeli, 2013) investigated the production of concretes containing granulated slag of lead and zinc industry as sand replacement mixed in different proportions. The results showed that, the concrete mixed with granulated slag of lead and zinc as a sand replacement has higher compressive strength. Also, granulated slag of lead and zinc incorporation resulted in an increase of the attenuation coefficient of gamma radiation.

In many cases, deterioration of concrete structures in nuclear facilities occurs by the surrounding marine environment since they are usually located near the sea to maintain a permanent source of flowing cooling water to the nuclear plant system. In a marine environment, the chloride ion penetrate into the concrete either from water or sea winds carrying salts ions which destroy the passivity of steel and lead to initiation of corrosion. On the other hand, the principal reason for the deleterious attack of sulfate on concrete is the formation of gypsum and a complex compound known as calcium sulphoaluminate (Ettringite). Both ettringite and corrosion products occupy greater volume after crystallization in the pores of concrete than the compounds they replace (Maes and Belie, 2014; Wegian, 2010; Mehta, 1986) found that the sulfate related expansion in concrete are associated with ettringite.

Corrosion of steel reinforcement in concrete is one of the major causes of premature deterioration of reinforced concrete structures leading to structural failure. Steel in concrete remains in the passive state in alkaline solution, but various contaminates such as chloride ions and carbon dioxide have a detrimental effect on passivity of steel (Ouda, 2015).

This study investigates some especial concrete having maximum compressive strength (gradeM60) (strength value of more $600 \mathrm{~kg} / \mathrm{cm}^{2}$ after 28 days) and high density of about $3 \mathrm{Ton} / \mathrm{m}^{3}$ to be used for nuclear radiation shielding (TS EN 206-1, 2002). Accordingly, it is necessary to use the high pozzolanic reactive cementitious material to make high performance concrete. Silica fume better than the other pozzolanic materials when used as a high pozzolanic reactive cementitious materials and $10 \%$ silica fume (SF) as a partial addition to ordinary Portland cement in the mix has been to be the most successful supplementary cementing materials (SCM) for heavy high performance concrete (Elhakam et al., 2012; Abo-El-Enein et al., 2014; Gharieb, 2014; Ouda, 2015).

\section{Experimental}

\subsection{Materials}

The materials used to produce heavy high performance concrete (HHPC - M60 grade) to use as radiation shielding concrete and high durability upon utilization in the establishment of nuclear facilities are: 
- Ordinary Portland cement (OPC - CEM1- 42.5 N), supplied from Suez Cement Company, Suez, Egypt.

- Silica fume (SF), provided from Ferro-Silicon Alloys Company, Edfo-Aswan, Egypt.

- The two types of coarse aggregates used are suitable for usage as a concrete component and satisfy the needed requirements for the construction of nuclear facilities:

a. Lead slag (LS), which is produced extensively as a by-product through lead production at the" Lead Production Company, Helwan, Egypt.

b. Crushed dolomite [CaMg$\left.\left(\mathrm{CO}_{3}\right)_{2}\right]$, obtained from Attaka area, Suez, Egypt.

Coarse aggregates were separated by manual sieving into various fractions of size $(5-20 \mathrm{~mm})$, according to Egyptian Standard Specification 1109 (2002) and ASTM C637(2009).

- The fine aggregate was local sand, washed at the site to remove deleterious materials and chloride contamination. In some concrete mixes, sand has been replaced by the fine fraction of lead slag to produce heavy density concrete according to TS EN 206-1 (2002).

The physical properties of coarse and fine aggregates are given in Table 1 . The chemical compositions of cement, silica fume, coarse aggregates and its fine portion shown in Table 2, were evaluated according to the limits specified by the ESS 1109 (2002) and ASTM C637 (2009).

The values of alkali silica reaction of samples of dolomite and lead slag aggregates were evaluated according to the limits specified by the ASTM 1260 (2014). It is evident that the expansion reached upon utilizing any of the coarse aggregates, dolomite $(0.053 \%)$ or lead slag $(0.080 \%)$ is below the expansion limit specified by the standard specification (i. e. not exceeding $0.1 \%)$ High performance concrete should have low water/binder ratio. Hence, effective dispersion of the mix is necessary to achieve proper workability without increasing the unit water concrete. This has been achieved by using a high rang water reducing Superplasticizer (SP)- type (G) to concrete mixes, compatible with ASTM C494 (2011).

\subsection{Sample preparation}

The slump test according to ASTM C143 (2010) was performed for fresh concrete, steel moulds cubes of $10 \times 10 \times 10 \mathrm{~cm}$ were used, The concrete was considered to be fully compacted. Following casting, concrete specimens were covered with a plastic sheet and kept in the laboratory at room temperature $23 \pm 2^{\circ} \mathrm{C}$ and relative humidity $100 \%$ for $24 \mathrm{~h}$. After de-molding, specimens were cured in water until the time of testing. Curing was done according to ASTM C511 (2009).

Table 1 . The physical properties of coarse and fine aggregates.

\begin{tabular}{|c|c|c|c|c|c|c|}
\hline \multirow{2}{*}{$\begin{array}{l}\text { Physical \& mechanical } \\
\text { properties. }\end{array}$} & \multirow{2}{*}{ Sand } & \multicolumn{2}{|c|}{ Dolomite } & \multicolumn{2}{|c|}{ Lead slag } & \multirow{2}{*}{$\begin{array}{c}\text { Limits of } \\
\text { coarse } \\
\text { aggregates }\end{array}$} \\
\hline & & Coarse & Fine & Coarse & Fine & \\
\hline Specific gravity, $\left(\mathrm{g} / \mathrm{cm}^{3}\right)$ & 2.65 & 2.60 & 2.79 & 3.51 & 3.57 & - \\
\hline Unit weight, (ton $/ \mathrm{m}^{3}$ ) & 1.62 & 1.46 & 1.79 & 2.12 & 2.61 & - \\
\hline $\begin{array}{l}\text { Clay and fine materials } \\
(\%)\end{array}$ & 1.40 & 0.38 & 14.97 & 0.23 & 16.80 & $\begin{array}{l}\leq 4^{(1)} \\
\leq 10^{(3)}\end{array}$ \\
\hline Water absorption, (\%) & - & 0.79 & - & 0.60 & - & $\leq 2.5^{(1)}$ \\
\hline Flakiness index, $(\%)$ & - & 40.21 & - & 18.52 & - & $\leq 25^{(2)}$ \\
\hline Elongation index, $(\%)$ & - & 20.38 & - & 22.02 & - & $\leq 25^{(2)}$ \\
\hline Crushing value, (\%) & - & - & - & 13.10 & - & $\leq 30^{(2)}$ \\
\hline Impact value, (\%) & - & 12.01 & - & 25.01 & - & $\leq 45^{(1)}$ \\
\hline
\end{tabular}

(1) According to Egyptian Standard Specification No. 1109 (2002).

(2) According to Egyptian Code of Practice for Reinforced Concrete No.2032017).

(3) According to ASTM C637 (2009). 
Table 2. Chemical analysis of starting materials, (wt., \%).

\begin{tabular}{|c|c|c|c|c|c|}
\hline \multirow{2}{*}{ Oxides, (\%) } & \multicolumn{5}{|c}{ Chemical analysis of starting Materials } \\
\cline { 2 - 6 } & \multirow{2}{*}{ OPC } & \multirow{2}{*}{$\mathrm{SF}$} & \multicolumn{3}{c|}{ Coarse aggregates } \\
\cline { 4 - 6 } & & & Dolomite & Lead slag & Sand \\
\hline \hline $\mathrm{SiO}_{2}$ & 21.32 & 95.22 & 1.67 & 9.03 & 93.40 \\
\hline $\mathrm{Al}_{2} \mathrm{O}_{3}$ & 3.99 & 0.32 & 0.07 & 1.29 & 2.03 \\
\hline $\mathrm{Fe}_{2} \mathrm{O}_{3}$ & 3.15 & 0.85 & 0.01 & 64.57 & 0.98 \\
\hline $\mathrm{CaO}$ & 62.04 & 0.26 & 35.54 & 2.24 & 0.71 \\
\hline $\mathrm{MgO}$ & 2.51 & 0.55 & 17.51 & 0.27 & 0.25 \\
\hline $\mathrm{SO3}^{--}$ & 2.70 & 0.20 & 0.13 & 17.99 & 0.30 \\
\hline $\mathrm{Cl}^{-}$ & 0.01 & 0.05 & - & - & 0.08 \\
\hline $\mathrm{Na}_{2} \mathrm{O}$ & 0.26 & 0.37 & 0.04 & 0.69 & 0.38 \\
\hline $\mathrm{K}_{2} \mathrm{O}$ & 0.22 & 0.51 & 0.02 & 0.05 & 0.64 \\
\hline $\mathrm{TiO}_{2}$ & - & - & 0.01 & 0.23 & 0.17 \\
\hline $\mathrm{BaO}$ & - & - & - & 0.27 & - \\
\hline $\mathrm{P}_{2} \mathrm{O}_{5}$ & - & 0.06 & 0.01 & 0.15 & 0.06 \\
\hline $\mathrm{MnO}$ & - & 0.10 & - & 0.44 & 0.03 \\
\hline $\mathrm{V}_{2} \mathrm{O}_{5}$ & - & - & - & - & - \\
\hline $\mathrm{PbO}$ & - & - & - & 1.98 & - \\
\hline $\mathrm{CuO}$ & - & - & - & 0.32 & - \\
\hline $\mathrm{ZnO}$ & - & 0.02 & - & 0.37 & - \\
\hline $\mathrm{L} . \mathrm{O} . \mathrm{I}$ & 3.75 & 1.50 & 44.99 & 0.01 & 0.74 \\
\hline $\mathrm{Total}$ & 99.95 & 99.99 & 99.97 & 99.89 & 99.92 \\
\hline
\end{tabular}

Samples were tested for compressive strength after 7, 28 and 90 days of preparations. The crushed samples at each hydration time were first ground and then subjected to stopping of the hydration process using a mixture of acetone and methanol in the ratio of $1: 1$ by volume, followed by drying to $80^{\circ} \mathrm{C}$ for $24 \mathrm{~h}$ to prevent further hydration and the dried samples were kept in a desiccators for further analysis (Taha et al., 1981; Khater, 2010).

\subsection{Mix Proportion}

Mixes proportions of high performance concrete were reached to comply to grade M60 that having a strength value of more than $600 \mathrm{~kg} / \mathrm{cm}^{2}$ after 28 days, and by the addition of supplementary cementitious materials ( $10 \%$ silica fume), to the total cement content are given in Table 3. The free water content of all mixes has been limited by about $35 \%$ of the total binders in addition to water content absorbed by both coarse and fine aggregates. A substantial reduction of quantity of mixing water and getting a high workability is possible only with the use of superplasticizer. A Superplasticizer was used to maintain a constant slump of $10 \pm 2 \mathrm{~cm}$.

Table 3. Mixes proportions of heavy-weight concrete per $1 \mathbf{~ m}^{3}$.

\begin{tabular}{|c|c|c|c|c|c|c|c|c|}
\hline \multirow{3}{*}{ Mixes } & \multicolumn{8}{|c|}{ Concrete ingredients, $\left(\mathrm{kg} / \mathrm{m}^{3}\right)$} \\
\cline { 2 - 8 } & \multirow{2}{*}{ OPC } & \multirow{2}{*}{$\mathrm{SF}$} & \multirow{2}{*}{$\mathrm{W}$} & \multicolumn{2}{|c|}{ Fine aggregates } & \multicolumn{2}{c|}{ Coarse aggregates } & \multirow{2}{*}{ SP } \\
\cline { 5 - 9 } & & & & Sand & Fine & $\mathrm{D}$ & L-Slag & \\
\hline $\mathrm{D}_{\mathrm{S}}$ & 450 & 45 & 173 & 772 & - & 944 & - & 9.5 \\
\hline $\mathrm{LS}_{\mathrm{S}}$ & 450 & 45 & 173 & 902 & - & - & 1102 & 9.4 \\
\hline $\mathrm{LS}_{\mathrm{F}}$ & 450 & 45 & 173 & - & 1041 & - & 1273 & 13.8 \\
\hline
\end{tabular}

\section{Investigation}

\subsection{Density}

The density of fresh and hardened concrete was determined according to BS EN 12390- 7 (2009) as follow: 


$$
\rho=M / V=(M a-M w) / 1000
$$

Where, : Density of specimen, M: Mass of specimen, V: Volume of specimen, Ma: Mass of suspended specimen in air and Mw: Mass of suspended specimen in water.

\subsection{Compressive strength}

This test was performed for cubes after 7, 28 and 90 days of preparation. The maximum compressive strength values of tested concrete specimens were carried out using a $2000 \mathrm{kN}$ compression testing machine with a loading rate of $0.6 \mathrm{MPa} / \mathrm{s}$ according to BS EN 12390-3 (2001).

\subsection{Radiation attenuation tests}

The attenuation coefficient of gamma rays on concrete specimens were performed using sodium iodide activated with thallium $\mathrm{NaI}(\mathrm{Tl})$ scintillation detector connected with a computerized Multi Channel Analyzer (MCA). The utilized standard radiation sources comprised cesium-137 ( $\left.\mathrm{Cs}^{137}\right)$ and cobalt-60 $\left(\mathrm{Co}^{60}\right)$ radioactive elements with photon energies of $0.662 \mathrm{MeV}$ for $\mathrm{Cs}^{137}$ and two energy levels of 1.173 and $1.333 \mathrm{MeV}$ for $\mathrm{Co}^{60}$ with activities five micro curie (5 $\mu \mathrm{Ci}$ ). Specimens were dried at $105^{\circ} \mathrm{C}$ for 2 hours as recommended by Yilmaz et al. (2011), prior investigated. The attenuation coefficient of gamma rays was determined by measuring the fractional radiation intensity (Ix) passing through the thickness (x) as compared to the source intensity (Io). The linear attenuation coefficient $(\mu)$ has been obtained from the solution of the exponential Beer-Lambert's law (Kharita et al., 2008):

$$
\mathbf{I x}=\mathbf{I o} \mathbf{e}^{-\mu \mathbf{x}}
$$

\subsection{Sea water exposure effects}

The concrete cubic specimens of dimensions $10 \times 10 \times 10 \mathrm{~cm}$ were cast in the laboratory. Then, the specimens were kept at $23 \pm 1{ }^{\circ} \mathrm{C}$ and $90 \%$ relative humidity for 24 hours. After demoulding, the concrete specimens were cured in tap water for 28 days (zero time) at room temperature, and then immersed in seawater tank for 1, 3 and 6 months. At each age of immersion, the specimens were subjected to compressive strength measurement and variations in the structure were studied using SEM techniques with respect to the reference samples after curing in tap water up to 28 days. Also, sea water has been renewed continuously to maintain the concentration of the immersion medium.

\subsection{Testing the corrosion of reinforcing steel in concrete}

\subsubsection{Preparation of reinforcing steel}

The reinforcing steel used in the present investigation was mild steel bars with diameter of 8 $\mathrm{mm}$. The steel rods were mechanically polished to remove the firmly adherent mill scales on the surface of steel and degreased with acetone, then coated with wax so that a predetermined area was always exposed between the waxed areas (El-Sayed et al., 1998; El-Sayed et al., 2000).

\subsubsection{Preparation of steel in concrete electrodes}

The reinforcing steel rods were centrally placed in cylindrical $5 \times 10 \mathrm{~cm}$ steel moulds, and the active areas of the rods were completely covered by the prepared compacted concrete. The concrete specimens were cured for ( $24 \mathrm{hrs}$.) after casting at room temperature $27 \pm 2{ }^{\circ} \mathrm{C}$, then demoulded and continuously cured for 28 days in sea water then tested in sea water, simulating the medium that will affect the concrete during actual service in the nuclear power plant. 


\subsubsection{Electrochemical measurements.}

Several electrochemical techniques can be employed to evaluate the corrosion risk of the reinforcing steel in concrete. Among them are open circuit potential (OCP), linear polarization resistance (LP) and concrete resistivity measurement (Andrade and Alonso, 2004; Millard et al., 2001; Gonzalez et al., 1995; Song and Saraswathy, 2007; Elshami, 2012).

\section{Results and discussion}

\subsection{Density of tested concrete}

The density values of fresh and hardened concrete mixes made with dolomite and lead slag coarse aggregates and fine aggregate of local sand or replacing sand by the fine portion of the raw aggregates are given in Table 4. The results show that, the concrete containing lead slag aggregate is higher density than that of the concrete containing dolomite aggregates by $18 \%$. This is due to lead slag aggregate has higher specific gravity value than the dolomite aggregates. The results indicate also that, the density of the concrete increases by about $20 \%$ upon replacing sand by the fine portion of lead slag aggregate.

Table 4. Physical properties of the concrete mixes.

\begin{tabular}{|c|c|c|c|}
\hline \multirow{2}{*}{ Mixes } & \multicolumn{3}{|c|}{ Physical properties } \\
\cline { 2 - 4 } & \multirow{2}{*}{ Slump, (cm) } & \multicolumn{2}{|c|}{ Density, (Ton/m ${ }^{3}$ ) } \\
\cline { 3 - 4 } & & fresh concrete & Hardened concrete \\
\hline \hline $\mathrm{D}_{\mathrm{S}}$ & 9 & 2.45 & 2.41 \\
\hline $\mathrm{LS}_{\mathrm{S}}$ & 10 & 2.84 & 2.84 \\
\hline $\mathrm{LS}_{\mathrm{F}}$ & 8 & 3.45 & 3.41 \\
\hline
\end{tabular}

\subsection{Compressive strength of tested Concrete.}

The compressive strength results of concrete mixes are given in Fig. 1. The results reveal that, the compressive strength of the all hardened concrete mixes increases with the increase of age. This is mainly due to the progress of hydration process with curing time and increase of the amount of cement hydration products which deposited in the open pore system of the hardened leading to a decrease in the total porosity as well as an increase in the total contents of binding centers in the specimens; this leads may be to an increase in the compressive strength. The results indicate that, for all concrete mixes made with dolomite and lead slag coarse aggregates and containing $10 \%$ silica fume satisfy the requirements of compressive strength for high performance concrete (grad-M60) after 28 days of curing. This enhancement in the compressive strength is mainly due to the physical and chemical effects of silica fume with its fineness and high silica content provides a filler effect and a pozzolanic reaction, causing pore refinement process and further densification of the transition zone occurring due to the conversion of lime forming from the hydration of cement into additional binding materials through lime-pozzolanic reaction that lead to improve the mechanical performance of the heavy concrete.

The results indicate also that, the compressive strength values of the hardened lead slag concrete containing lead slag as a fine aggregate are higher than those containing sand specimen by $27 \%$ and $24 \%$ at 28 and 90 days, respectively. The improvement in compressive strength due to the concaved holes and micro-pores on the surface of crushed coarse aggregate are filled with mortar and hydrated cement paste which increases the interlocking and the mechanical bond between the aggregate particles and cement matrix in concrete. 


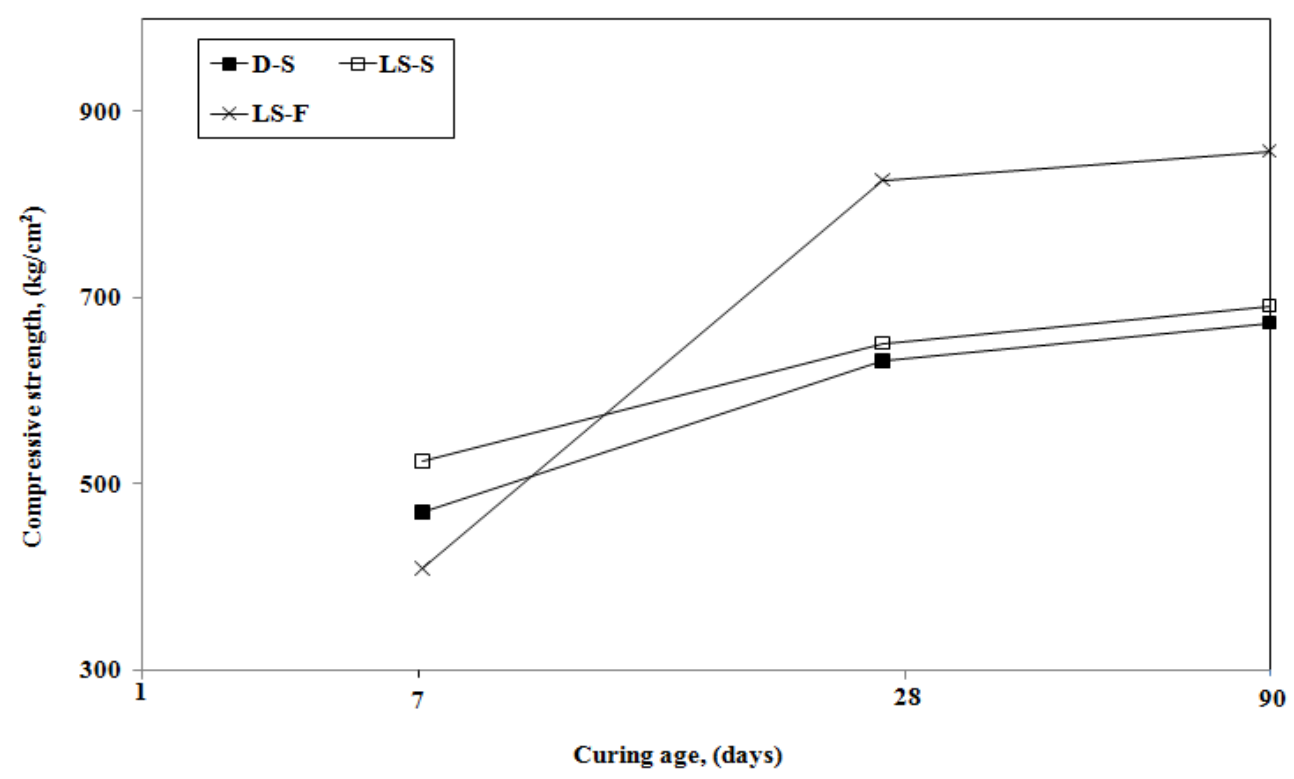

Fig. 1. Compressive strength of concrete made with dolomite and lead slag aggregates cured in tap water up to 90 days.

\subsection{Radiation investigation}

The liner attenuation coefficient $(\mu)$ measurements has been carried out using a collimated beam of the point isotropic $\gamma$-rays source $\mathrm{Cs}^{173}$, with one line of energy $[\mathrm{E}=662 \mathrm{KeV}]$ and $\mathrm{Co}^{60}$ with two lines $[E 1=1173 \mathrm{KeV}$ and $\mathrm{E} 2=1333 \mathrm{KeV}]$ are given in Fig. 2 . The results reveal that, the total linear attenuations coefficient $(\mu)$ of concrete mixes increases with an increase in concrete density $(\rho)$. Therefore, the concrete mix containing lead slag aggregate $(\rho=2.84)$ shows the highest attenuation coefficient than that containing dolomite aggregate $(\rho=2.41)$. The results indicate also that, the total linear attenuation coefficient $(\mu)$ increases upon replacing sand by the fine portions of lead slag aggregate (for energy of $0.662,1.173$ and $1.332 \mathrm{MeV}$ ). This is mainly due to the concrete mixes made with fine portions of lead slag aggregate more density than concrete mixes made with local sand. Whereas, the density of concrete made with fine lead slag aggregates increase by $20 \%$, than concrete made with local sand as fine aggregate.

\subsection{Effect of sea water on the mechanical properties of high performance concrete (HPC)}

\subsubsection{Compressive strength}

The compressive strength values of HPC mixes made with dolomite and lead slag aggregates and fine aggregate of local sand or replacing sand by the fine portion of raw coarse aggregates and containing $10 \%$ silica fume as a partial additive to OPC, cured in tap water up to 28 days (zero time), then immersed in sea water for 1, 3 and 6 months are graphically represented in Fig. 3. The results reveal that, the compressive strength values of the concrete made of lead slag aggregate incorporating their fine portions as the fine aggregate are higher than the concrete incorporating sand as the fine aggregate. This is due to the high fineness of the lead slag fine portions leading to high compaction of the concrete enhancing the resulting strength. However, all the recorded strength values satisfy the requirements of the high performance concrete (grade M-60) (i. e. exceeding $600 \mathrm{~kg} / \mathrm{cm}^{2}$ ).

The results reveal also that, the compressive strength of concrete mixes made with dolomite coarse aggregate exhibit a slight increase upon immersion in sea water for 1 month, then decrease upon increasing the immersion time in sea water. On the other hand, the compressive 
strength values for the other concrete mixes decrease with the progress of the immersion time in sea water. The compressive strength increase at early immersion time is mainly due to the pozzolanic reactivity of silica fume, causing pore refinement process and further densification of the transition zone between the matrix and the coarse aggregates to give a more compact closed body structure. In addition to the existence of calcium chloride in sea water that accelerate the hardening process of concrete. This leads to compressive strength enhancement. The compressive strength decrease with increased immersion time in sea water up to 6 months may be due to the aggressive attack of chloride and sulphate ions present in sea water and formation of detrimental voluminous expansive compounds e. g. gypsum, ettringite and calcium chloroaluminate (Freidel's salt).

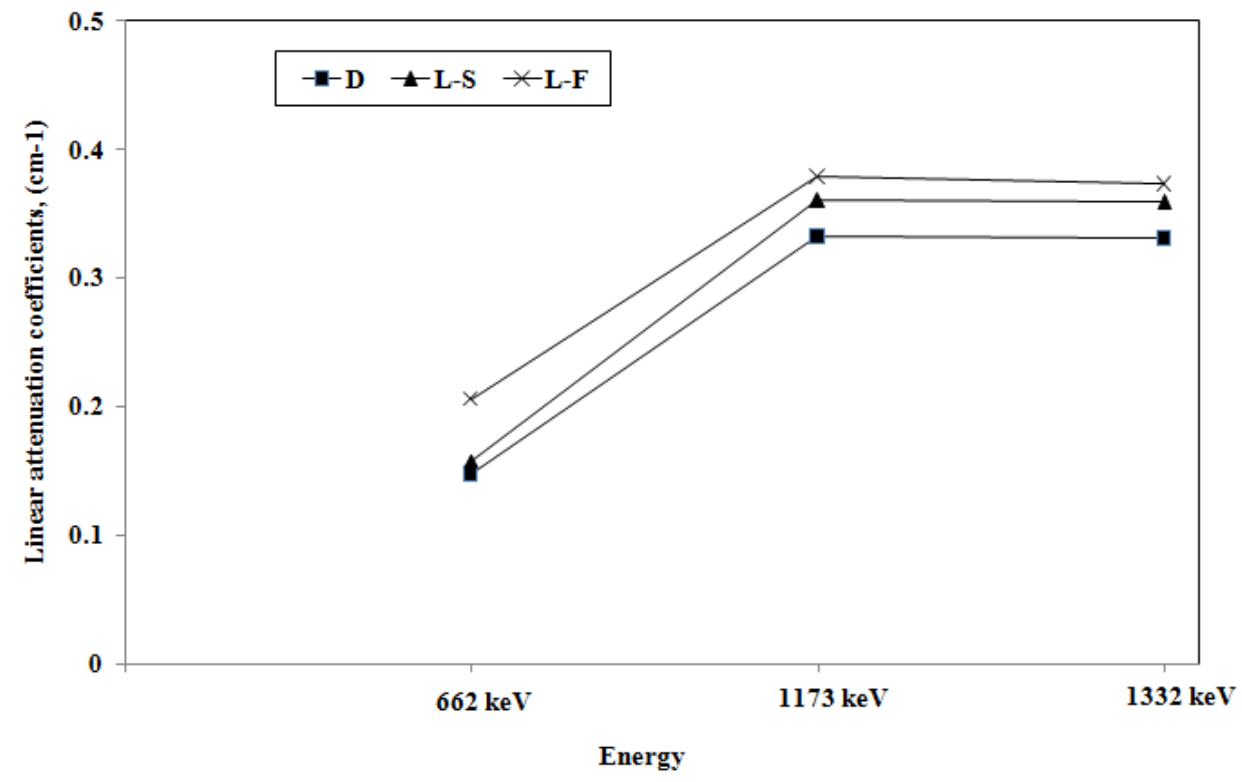

Fig. 2. Linear attenuation coefficients of the high performance concrete containing different coarse aggregates using $\mathrm{Cs}^{137}$ and $\mathrm{Co}^{60}$ sources.

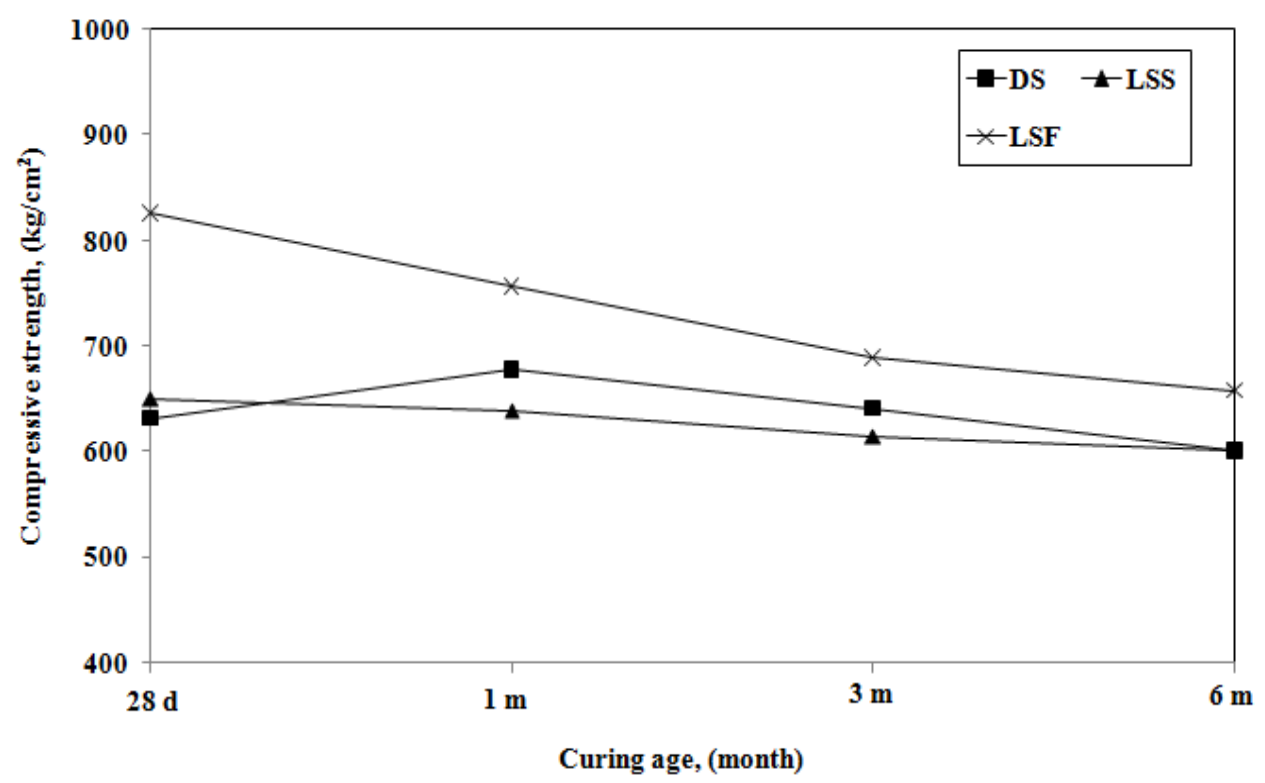

Fig. 3. Compressive strength of concrete containing different coarse aggregates, immersed in sea water up to 6 months. 


\subsubsection{Scanning electron microscopy (SEM) investigation}

The SEM micrographs obtained for the high performance concrete made with dolomite and lead slag aggregates and fine aggregate of local sand or replacing sand by fine portion of lead slag aggregates and curing in tap water up to 28 days, then immersed in sea water up to 6 months are shown in Fig. 4.

Fig. 4(a) shows the micrographs of dolomite concrete. The micrographs of the dolomite concrete cured in tap water for 28 days, indicates the growth of hydration products, and increase in the amount of CSH phase which filled the available pores. After 6 months immersion in sea water Fig. 4 (à), the dolomite concrete displayed the formation of micro-cracks spread throughout the concrete matrix particularly at the interfacial transition zone (ITZ) between the aggregate particles and cement paste. That caused the decrease in the compressive strength.

Fig. 4 (b, c) show the micrographs of lead slag concrete with fine sand (b), and lead slag concrete with fine lead slag (c). The SEM micrographs showed a relatively dense and compact microstructure with curing in tap water up to 28 days. This is due to the pozzolanic reaction of amorphous silica of silica fume with $\mathrm{Ca}(\mathrm{OH})_{2}$ produced from cement hydration to form additional amounts of CSH gel which deposited in the pore system. After 6 months immersion in sea water (Fig. 4 ( $\left.b^{\prime}, c^{\prime}\right)$ ), the lead slag concrete displayed the presence of little change in the micrographs throughout the concrete matrix particularly at the ITZ between the aggregate particles and cement paste. This is due to the ingress of sulphate and chloride ions from sea water into the cementitious matrix and reacts with hydrated cement produce and form expansive products that leading to slight decrease in the compressive strength.
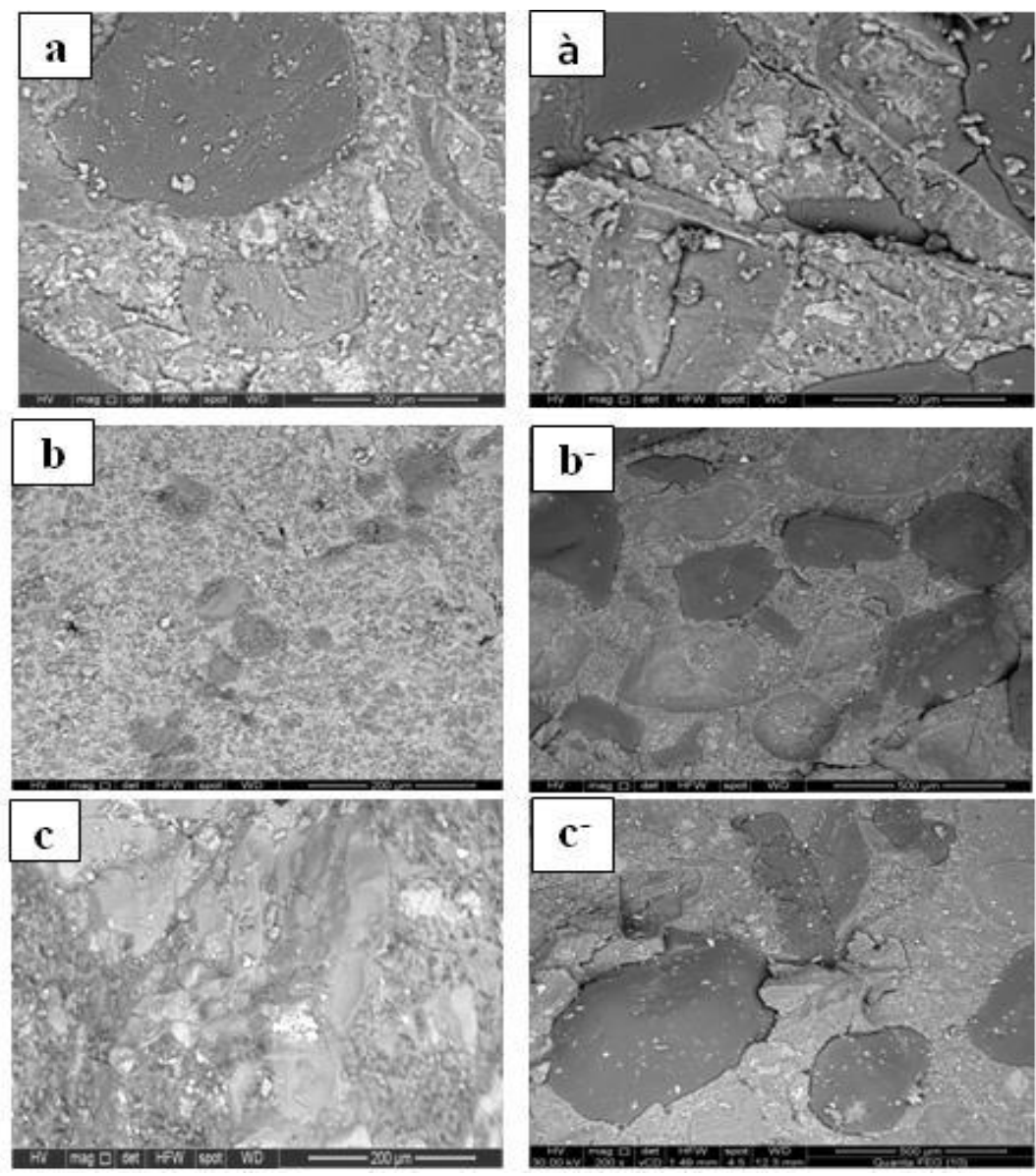

Fig. 4. SEM micrographs of dolomite concrete (a), lead slag concrete with fine sand (b), and lead slag concrete with fine lead slag (c) for 28 days in tap water, then immersing in sea water up to 6 months (à), (b') and (c’), respectively. 


\subsection{Corrosion behavior of reinforcing steel embedded in concrete incorporating different heavy aggregates upon exposure to sea water}

\subsubsection{Open circuit potential (OCP)}

Fig. 5 shows the variation of corrosion potential with time of reinforcing steel embedded in high performance concrete incorporating dolomite and leads slag coarse aggregates, and fine aggregates of local sand or replacing sand by the fine portion of the raw aggregates, immersed in sea water for 28 days. Fig. 5 reveals that, the potential of steel in the dolomite concrete starts at $-153 \mathrm{mV}$, then slightly shifts in the negative direction until reaching the steady state value of $-238 \mathrm{mV}$. These results indicate that, the corrosion condition of steel in dolomite concrete is at intermediate corrosion risk. While, the corrosion potential values of reinforcing steel in lead slag concrete submerged in sea water starts at $-183 \mathrm{mV}$, then increases in the negative direction until reaching the steady state value at $-363 \mathrm{mV}$. This indicates that, the steel susceptibility to corrosion is high. The results indicate that, the potential of the steel in the lead slag concrete containing fine lead slag starts at $-378 \mathrm{mV}$, then increases in the negative direction until reaching the steady state value at $-442 \mathrm{mV}$, revealing a tendency to corrode.

\subsubsection{Linear polarization (LP) and polarization resistance measurements}

As can be seen from Table 5, the polarization (electrical) resistivity of concrete is inversely proportional to the embedded steel corrosion rate. In other words, low concrete polarization resistance will facilitate the ingress and penetration of aggressive ions till reaching the embedded steel hence endangering its passivity and increasing the corrosion risk as appeared by the corrosion rate increment.

Table 5 presents the polarization resistance $(\mathrm{Rp})$, the corrosion current density $\left(\mathrm{I}_{\text {corr. }}\right)$ and the corrosion rates of reinforcing steel embedded in high performance concrete incorporating dolomite and lead slag coarse aggregates and fine aggregate of sand or replacing sand by the fine portion of the raw coarse aggregates, immersed in sea water for 28 days. It can be seen that, lead slag concrete having sand or lead slag fine portion as the fine aggregate offer the lowest polarization resistance values and, consequently, the highest corrosion rate. On the other hand, dolomite concrete offers the highest polarization resistance values, the lowest corrosion rate values.

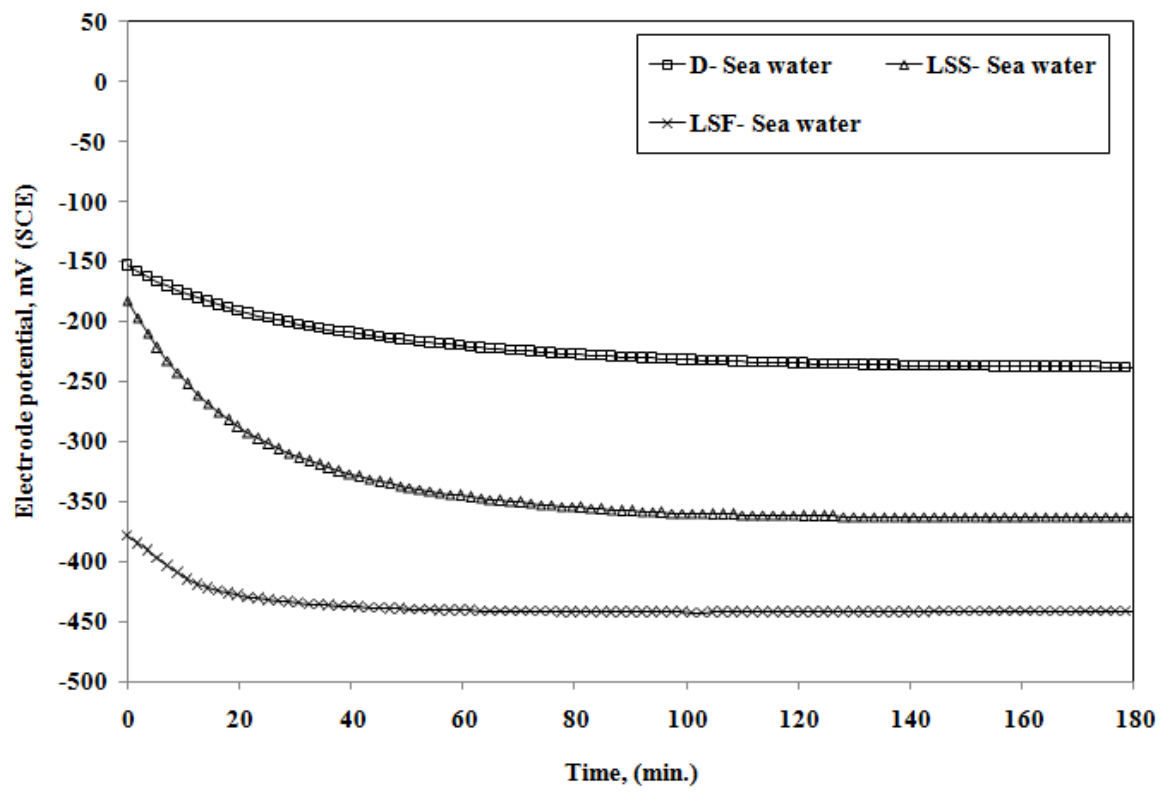

Fig. 5. Open-circuit potential/ time curves of steel in high performance concrete containing dolomite and lead slag aggregates, immersed in seawater for 28 days. 
Table 5. Corrosion risk for steel in high performance concrete containing dolomite and lead slag aggregates, immersed in sea water for $\mathbf{2 8}$ days.

\begin{tabular}{|c|c|c|c|}
\hline $\begin{array}{c}\text { Sample } \\
\text { Code }\end{array}$ & $\begin{array}{c}\text { Polarization resistance, } \\
\mathrm{R}_{\mathrm{P}}\left(\mathrm{k} \Omega . \mathrm{cm}^{2}\right)\end{array}$ & $\begin{array}{c}\text { Corrosion Current density, } \\
\mathrm{I}_{\text {corr }}\left(\mu \mathrm{A} / \mathrm{cm}^{2}\right)\end{array}$ & $\begin{array}{c}\text { Corrosion rate, } \\
(\mu \mathrm{m} / \text { year })\end{array}$ \\
\hline \hline $\mathrm{D}_{\mathrm{S}}$ & 129 & 0.692 & 1.892 \\
\hline $\mathrm{LS}_{\mathrm{S}}$ & 82 & 0.988 & 2.679 \\
\hline $\mathrm{LS}_{\mathrm{F}}$ & 63 & 1.302 & 3.821 \\
\hline
\end{tabular}

\section{Conclusions}

1. The slump values of the heavy concrete decreases while, the density increases upon replacing sand by the fine portion of magnetite and lead slag aggregates.

2. The compressive strength for all concrete mixes made with dolomite and lead slag coarse aggregates and containing $10 \%$ silica fume satisfy the requirements of compressive strength for high performance concrete (grade-M60) after 28 days of curing in tap water.

3. The compressive strength values and gamma shielding properties of concrete mixes containing lead slag aggregate enhances upon replacing sand by fine portion of lead slag aggregate.

4. The concrete mixes made with lead slag coarse aggregate preferably with their fine portion as the fine aggregate - proved their high endurance and could sustain sea water exposure, achieving compressive strength values exceeding grade M-60 concrete even after 6 months exposure.

5. Lead slag concrete inspite of its efficient durability requires the incorporation of a corrosion inhibitor to counteract the hostile effect of the high sulfate concrete in the aggregate.

\section{References}

Abo-El-Enein, S. A., El-Sayed, H. A., Ali, A. H., Mohammed, Y. T., Khater, H. M., \& Ouda, A. S. (2014). Physicomechanical properties of high performance concrete using different aggregates in presence of silica fume. HBRC Journal, 10(1), 43-48.

Akkurt, I., Başyigit, C., Akkaş, A., Kilingarslan, Ş., Mavi, B., \& Giinoglu, K. (2012). Determination of some heavyweight aggregate half value layer thickness used for radiation shielding. Acta Physica Polonica-Series A General Physics, 121(1), 138.

Al-Humaiqani, M. M., Shuraim, A .B. \&Hussain, R. R. (2013). $\gamma$-Radiation Shielding Properties of High Strength High Performance Concretes Prepared with Different Types of Normal and Heavy Aggregates, Asian Transactions on Engineering, (ATE ISSN: 2221-4267), 03,18-28.

Alwaeli, M. (2013). Application of granulated lead-zinc slag in concrete as an opportunity to save natural resources. Radiation Physics and Chemistry, 83, 54-60.

Andrade, C., \& Alonso, C. (2004). Test methods for on-site corrosion rate measurement of steel reinforcement in concrete by means of the polarization resistance method. Materials and Structures, 37(9), 623-643.

ASTM 1260, (2014). Standard Specification for Alkali aggregate reaction for Concrete.

ASTM C143, (2010). Standard Test Method for Slump of Hydraulic Cement Concrete.

ASTM C494, (2011). Standard Specification for Chemical Admixtures for Concrete.

ASTM C511, (2009). Standard Specification for Mixing Rooms, Moist Cabinets, Moist Rooms and Water Storage Tanks Used in the Testing of Hydraulic Cements and Concretes. 
ASTM C637, (2009). Standard Specification for Aggregates for Radiation-Shielding Concrete.

ASTM C637, (2009). Standard Specification for Aggregates for Radiation-Shielding Concrete.

Atzeni, C., Massidda, L., \& Sanna, U. (1996). Use of granulated slag from lead and zinc processing in concrete technology. Cement and concrete research, 26(9), 1381-1388.

BS, EN 12390-3, (2001). Testing Hardened Concrete - Part 3: Compressive Strength of Test Specimens.

BS, EN 12390-7, (2009). Testing Hardened Concrete, Density of Hardened, Concrete.

Egyptian Code of Practice 203, (2017). For Reinforced Concrete.

Egyptian Standard Specification 1109, (2002). Concrete Aggregates from Natural Sources.

Egyptian Standard Specifications No. 1109, (2002). Concrete Aggregates from Natural Sources.

Elhakam, A. A., Mohamed, A. E., \& Awad, E. (2012). Influence of self-healing, mixing method and adding silica fume on mechanical properties of recycled aggregates concrete. Construction and Building Materials, 35, 421-427.

El-Sayed, A. (2002). Calculation of the cross-sections for fast neutrons and gamma-rays in concrete shields. Annals of Nuclear Energy, 29(16), 1977-1988.

El-Sayed, H. A., Ali, H. A., El-Sabbagh, B. A. \&Hassan, H. M. (1998). Role of an Innovated Waste Product Mix in Promoting Concrete Characteristics: (a) Strength and Durability, $8^{\text {th }}$ Int. Confr. On Environmental Protection is a Must", Alexandria, Egypt.

El-Sayed, H. A., El-Sabbagh, B. A., \& Hassan, H. M. (2000). Role of an Innovated Waste Product Mix in Promoting Concrete Characteristics: (b) Corrosion Protection of Steel Reinforcement, Egyptian Journal of Applied Sciences, 15(8), 1.

Elshami, A. (2012). Efficiency of corrosion inhibitors used for concrete structures in aggressive environment, Ph. D. Thesis, in Materials Science for Engineers, Nantes University.

Gharieb, M. (2014). Studied on the physico-chemical and mechanical characteristic of the hardened blended cement pastes containing some industrial wastes, B.Sc. Thesis Faculty of science, AlAzhar University.

Gonzalez, J. A., Andrade, C., Alonso, C., \& Feliu, S. (1995). Comparison of rates of general corrosion and maximum pitting penetration on concrete embedded steel reinforcement. Cement and concrete research, 25(2), 257-264.

Kharita, M. H., Takeyeddin, M., Alnassar, M., \& Yousef, S. (2008). Development of special radiation shielding concretes using natural local materials and evaluation of their shielding characteristics. Progress in Nuclear energy, 50(1), 33-36.

Khater, H. M. (2010). Influence of metakaolin on resistivity of cement mortar to magnesium chloride solution. Ceramics-Silikáty, 54(4), 325-333.

Maes, M., \& De Belie, N. (2014). Resistance of concrete and mortar against combined attack of chloride and sodium sulphate. Cement and Concrete Composites, 53, 59-72.

Mehta, P. K. (1986). Concrete-Structures, Properties and Materials, Prentice-Hall, Inc., Englewood Cliffs. New Jersey, 105-169.

Millard, S. G., Law, D., Bungey, J. H., \& Cairns, J. (2001). Environmental influences on linear polarisation corrosion rate measurement in reinforced concrete. NDT \& E International, 34(6), 409-417.

Ouda, A. S. (2014). Development of high-performance heavy density concrete using different aggregates for gamma-ray shielding, Advances in Civil, Environmental and Materials Research, (ACEM 14), 24-28.

Ouda, A. S. (2015). Development of high-performance heavy density concrete using different aggregates for gamma-ray shielding. Progress in Nuclear Energy, 79, 48-55.

Song, H., \& Saraswathy, V. (2007). Corrosion Monitoring of Reinforced Concrete Structures-A Review, Int. J. Electrochem. Sci., 2, 1-28. 
Taha, A. S., El-Didamony, H., Abo EL-Enein, S. A., \& Amer, H. A. (1981). Physicochemical properties of Supersulphated Cement Pastes, Zement-Kalk-Gips, 34(6), 351-353.

TS EN 206-1. Concrete-Part 1(2002): Specification, Performance, Production and conformity T.S. Ankara: Turkey.

Wegian, F. M. (2010). Effect of seawater for mixing and curing on structural concrete, The IES Journal Part A: Civil \& Structural Engineering, 3(4), 235-243.

Yılmaz, E., Baltas, H., Kırıs, E., Ustabas, I., Cevik, U., \& El-Khayatt, A. M. (2011). Gamma ray and neutron shielding properties of some concrete materials. Annals of Nuclear Energy, 38(10), 2204-2212. 